\title{
Effects of Retailers' Corporate Social Responsibility on Retailer Equity and Consumer Usage Intention
}

\author{
Seong Ho Lee
}

Citation: Lee, S.H. Effects of Retailers' Corporate Social Responsibility on Retailer Equity and Consumer Usage Intention. Sustainability 2021, 13, 3080. https:// doi.org/10.3390/su13063080

Academic Editor: Roberta Costa

Received: 25 January 2021

Accepted: 8 March 2021

Published: 11 March 2021

Publisher's Note: MDPI stays neutral with regard to jurisdictional claims in published maps and institutional affiliations.

Copyright: (C) 2021 by the author. Licensee MDPI, Basel, Switzerland. This article is an open access article distributed under the terms and conditions of the Creative Commons Attribution (CC BY) license (https:/ / creativecommons.org/licenses/by/ $4.0 /)$.
Department of Business Administration \& Accounting, Hanbat National University, Daejeon 34158, Korea; 1sh33@hanbat.ac.kr; Tel.: +82-42-821-1376

\begin{abstract}
This study focused on corporate social responsibility (CSR) to examine how retailers can distinguish themselves in the market and attain sustainability. It thus investigated the correlation between CSR, retailer equity, and consumer usage intention to explain the role of CSR activities. For this study, data were gathered from 357 customers who were doing business (i.e., shopping) with retailers, and they were analyzed using structural equation modeling. Results indicated that retailers' CSR activities had a positive effect on retailer equity, which then had a significant positive effect on customer usage intention. The results further showed that consumers observe retailer equity when they experience its CSR activities, which increased their intention to shop with the retailer. The findings indicated that retailers' CSR was an attractive factor making retailers stand out in the market, and attain sustainability, and that CSR improved both retailer equity and customer usage intention. This study has academic implications in that it finds a brand-new outcome variable of retailers' CSR, such as retailer equity. In addition, it also has practical implications in managing and developing retailers' CSR as an important marketing strategy.
\end{abstract}

Keywords: corporate social responsibility; marketing; retailer equity; usage intention

\section{Introduction}

As the markets are becoming increasingly globalized and competitive, retailers are focusing their efforts on finding ways to distinguish themselves from their competitors. Traditionally, price has been a major strategy used for this purpose; however, the price competitiveness alone has now made it difficult for retailers to stand out because it is easy to imitate competitors, and the differences in the price image among competitors continue to decrease [1]. Considering this trend, retailers can find a way to detach themselves from corporate social responsibility (CSR). Customers trust retailers who implement CSR activities, and even switch to retailers who are implementing CSR activities well, even if the price and quality of the products may be similar. This suggests that CSR can be used to distinguish retailers from their competitors [2]. CSR activities have a positive effect on strengthening the brand and create a synergy in brand enhancement with a company's marketing. Therefore, retailers need to promote their brands so as to obtain unique and positive responses compared to their competitors through CSR activities. In other words, CSR can be a great tool for companies to make themselves stand out in the market and create positive feelings among consumers [3].

Due to the positive effects of CSR, industrial and academic interest in CSR has been growing; and at the same time, CSR has increasingly become an important strategic issue for businesses [4]. However, while most studies in this field tend to take a corporate perspective, there are relatively few studies that adopt a consumer perspective [4-6]. However, retailers still need to understand how consumers perceive and respond to their CSR activities when implementing a CSR strategy [7].

Therefore, to compensate for this lack of research which considers the consumer's point of view, this study attempted to deal with retailer equity as an important CSR 
outcome variable. Retailer equity is the consumer-based concept that stands for the overall assessment of the retail products as a differential effect of retailer knowledge on customer response to the retailer's marketing [8]. This study thus identified how retailers' CSR activities resulted in the recognition of retailer equity, which was customers' overall assessment of retailers. The influence of the retailer's CSR on retailer equity has been absent from the literature so far, therefore this study has implications with regard to exploring a new customer-based variable affected by the CSR. Ultimately, identifying the relationship between the CSR and retailer quality will represent an opportunity to understand how customers perceive and respond to retailers' CSR activities.

Meanwhile, previous studies could not agree on the relationship between the CSR and performance. Several studies showed that CSR had a positive impact on corporate performance, such as returns on investments, sales growth, and market share (e.g., [9-12]). In addition, retailers' CSR activities had a positive impact on consumer attitudes toward the retailer [13-16] and consumers' purchasing intentions [3,17]. However, studies have shown that CSR can also damage the corporate value and performance (e.g., [18-20]). In addition, CSR did not directly affect consumers' future behavioral intentions, such as purchases or loyalty [1,21].

Scholars argued that these inconsistencies may be due to some other conditional or moderate variables [11,22-24]. That is, these inconsistent arguments show that it is important to identify what the mediator or moderate variables are between the CSR and performance. Therefore, this study aimed to demonstrate the relationship by establishing retailer equity as an important mediator variable. The concept of retailer equity refers to a value that the consumer associates with the retailer's name, and a symbol such as the customer-based brand equity [25,26]. Therefore, it defines retailer assets based on customer or marketing perspectives rather than on the concept of financial assets $[8,27]$.

The specific purpose of this study is (1) to verify whether the customer's perception of retailers' CSR activities affects the positive assessment of their equity; and (2) to determine whether consumer-based retailer equity, which is affected by retailers' CSR activities, ultimately increases consumers' intention to use the retailer.

The study outline is as follows: First, research models and hypotheses are developed considering prior studies. Second, detailed results are presented through an empirical analysis of the hypotheses. Third, the results are discussed considering academic and managerial implications. Finally, research limitations and recommendations for further research are addressed in the final section.

\section{Literature Review and Hypotheses Development \\ 2.1. Retailer's CSR: Retailer Equity}

CSR is associated with a wide variety of issues which range from corporate profitability and economic stability to social safety and, ultimately, conservation of the ecology [28]. CSR can be defined as an organization's ethical behavior and social obligations beyond the organization's financial interests [29]. In other words, CSR refers to the responsibilities that a firm has considering its circumstances [30]. Despite its long history, no agreement has been made between industry participants, academics or other interested parties in the definition of CSR. In other words, the definition of CSR is complex and complicated [28]. Sheehy [28] defined CSR clearly as international private business self-regulation after a careful review of the CSR debates.

Retailers' CSR covered in this study is not as simple as manufacturers' CSR. Retailers are not only expected to behave responsibly in their own business practices, but also to provide products produced sustainably by suppliers. In addition, while other industries within supply chains may address their own immediate environmental, community issues or workplace problems, CSR in the retail industry should focus on issues from practices in the supply chain to consumer pressures, not on their own immediate practices [31].

Nevertheless, their CSR activities are becoming crucial in severe retail competition because CSR is strategically important for retailers [32]. The specific reasons why CSR 
research has become important in retail are as follows: First, retailers are motivated to operate in a socially responsible manner to satisfy customers' demand or desire for ethical consumption, which is particularly important in a consumer-oriented industry such as retail because retailers can directly influence CSR-related issues through their relationship with consumers [33].

Second, studies on the relationship between CSR and financial performance showed that companies that emphasize the sustainability of the environment and society through CSR had better financial performance compared to others in the same industry [34-36].

To summarize the noneconomic outcomes in CSR-related studies, consumer attitude, perceptions [37,38], customer loyalty [39], and customer relationships [40] are representative in consumer perspective CSR studies. In particular, retailers' CSR activities directly affect their attitudes and relationships with the customer in the retail sector [1].

The CSR activities also have a positive effect on brand strengthening. Mark-Herbert and Von Schantz [41] found that CSR activities resulted in a key component of creating a strong brand when delivered effectively. In addition, a company's marketing and CSR activities create a synergy in brand enhancement [42]. Therefore, we can assume that the CSR activities also have a positive effect on retailer equity, a concept that refers to the brand assets of retailers that considers retailers as a series of brands. High retailer equity allows customers to easily distinguish and recall retailers, have many positive and strong images associated with them, perceive them as high-quality retailers, and be loyal to them [43]. Several CSR studies have demonstrated positive effects on the factors that make up retailer equity, such as retailer awareness, image, perceived quality, and loyalty. The most important and fundamental first step in retailer equity is retailer awareness, and CSR has a positive effect on it. Mattera, Baena, and Cerviño [30] analyzed the relationship between the CSR activities and brand awareness of service companies using the ISO 26000 certification and global reporting initiative (GRI) as representative indicators related to CSR. The study found that ISO 26000 certification and GRI reviews served to inform customers that the company was doing well in its CSR activities, which ultimately improves the consumer's awareness of retailers. As customers' awareness of retailers increases through CSR activities, at the same time, the positive image of CSR activities spills over on to the retailers, which eventually helps them to develop a positive retailer image. Various studies have demonstrated that the CSR activities of retailers have a direct and positive effect on the image of retailers as brands (e.g., [5,6,17,21,44]).

In addition, CSR also has a positive effect on perceived quality and retailer loyalty as an important evaluation factor of the consumer-based retailer equity. CSR for the main hypermarkets has a direct and significant influence on perceived quality [44]. Appropriate CSR activities create the feeling that the company is reliable, which allows consumers to perceive a higher service quality [45]. In addition, several studies revealed that the CSR activities and CSR policies brought a positive influence on consumer loyalty for the retailer $[1,5,21,46]$. Therefore, based on these previous studies, CSR activities of retailers may improve the customer's perception of retailer equity.

Hypothesis 1 (H1). Retailers' CSR activities will have a positive effect on their equity.

\subsection{Retailer Equity: Usage Intention}

High retailer equity brings various benefits to retailers. Retailers with high brand equity levels have many advantages (e.g., non-elastic price sensitivity, continuous price premium, successful brand expansion, high market share, competitive cost structure, and high profitability) [47]. In other words, high retailer equity means the value added by the brand name to the retailer, and it is an essential differentiator for competitive advantage.

In addition, retailer equity also affects the relationship between retailers and customers. The retailer's brand strongly influences consumers' perceptions and drives their choices and builds their loyalty to the retailer in the relationship between the retailer and its customers [48]. 
Therefore, consumer-based retailer equity is deeply related to the consumer perspective variables such as consumer assessment of marketing activities, preference, and retailer choice [8]. Arnett et al. [25] developed an index for measuring retailer equity and validated the causal relationship between the retailer equity and shopping intention in an analysis to verify the nomological validity of the developed scale. As a result, they found that retailer equity had a positive effect on shopping intentions.

Most of all, considering the topic of this study, it is important to identify whether improved retailer equity through CSR activities has a structural, causal relationship that increases customer intention to use the retailer's products. Consumers' decisions on purchasing are influenced not only by tangible attributes such as price and quality, but also by intangible attributes such as company reputation and brand personality that can be built through CSR activities [49]. Therefore, based on these studies, enhanced retailer equity through CSR activities may increase the customer's willingness to use the retailer.

Hypothesis 2 (H2). Retailer equity will have a positive effect on the usage intention of customers.

Based on the literature review and hypotheses development, the research model is presented in Figure 1 as follows.

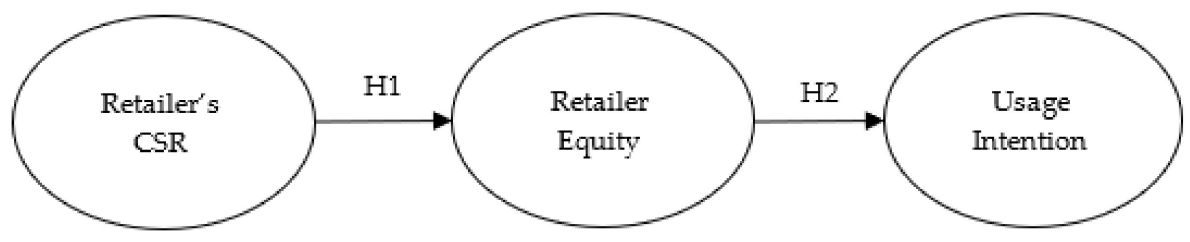

Figure 1. Research model.

\section{Methodology}

\subsection{Data Collection and Sampling}

We collected data by surveying consumers in South Korea. We asked them to fill out a self-administered questionnaire on the constructs of this study, such as retailer's CSR activities, retailer equity, and usage intention. In particular, respondents picked one familiar retailer and evaluated its CSR activities based on the employee, community, local product, and environmental support. We collected a total of 357 complete responses, excluding unfinished and missing data, out of the 370 questionnaires distributed.

In the demographic characteristics of the sample, there was a total of 171 men $(47.9 \%)$ and 186 women $(52.1 \%)$. As for age, 42 people $(11.8 \%)$ were in their $20 \mathrm{~s}, 109(30.5 \%)$ in their 30s, $102(28.6 \%)$ in their 40s, $98(27.5 \%)$ in their 50s, and 6 people $(1.7 \%)$ were aged $\geq 60$, respectively.

\subsection{Measurement Scales}

To develop measurements, we used the scales adopted and modified in previous studies. We applied a reflective measurement approach and 7-point Likert-type scale for all constructs (see Table 1). We adopted Sheehy's [28] definition, defining CSR as international private business self-regulation. The retailer's CSR activities were measured by four items which were adopted from the research of Ailawadi, Neslin, Luan, and Taylor [50], and Dang, Nguyen, and Pervan [51]. Retailer equity was measured by four items adopted from the research of Verhoef, Langerak, and Donkers [52], and Swoboda, Berg, and SchrammKlein [53]. Finally, we measured usage intention with three items adopted and modified from the research of Arnett, Laverie and Meiers [25]; Grace and O'Cass [54]; and Londoño, Elms, and Davies [55]. Detailed measurement items are given in the following Table 1. 
Table 1. Measurement items.

\begin{tabular}{ccc}
\hline Construct & Items & Reference \\
\hline Retailer's CSR & $\begin{array}{c}\text { I believe that Retailer A has environmentally friendly policies. } \\
\text { I believe that Retailer A cares about the local community. } \\
\text { I believe that Retailer A offers a large selection of local products. } \\
\text { I believe that Retailer A treats employees fairly. }\end{array}$ & $\begin{array}{c}\text { Ailawadi, Neslin, Luan, and Taylor (2014); } \\
\text { Dang, Nguyen, and Pervan (2020) }\end{array}$ \\
\hline Retailer Equity & $\begin{array}{c}\text { Retailer A is a strong brand. } \\
\text { Retailer A is a well-known brand. } \\
\text { Retailer A is a unique brand. }\end{array}$ & $\begin{array}{c}\text { Verhoef, Langerak, and Donkers (2007); Swoboda, Berg, } \\
\text { and Schramm-Klein (2013) }\end{array}$ \\
\hline Usage Intention & $\begin{array}{c}\text { I intend to use Retailer A. } \\
\text { I am planning to do shopping at Retailer A in the future. }\end{array}$ & $\begin{array}{c}\text { Arnett, Laverie and Meiers (2003); Grace and O'Cass } \\
\text { (2005); Londoño, Elms, and Davies (2017) }\end{array}$ \\
\hline
\end{tabular}

\section{Results}

\subsection{Reliability and Validity}

This study used the following measures: retailer's CSR activities, retailer equity, and usage intention. Verification of the measures employed a three-step approach: (1) analysis of reliability with Cronbach's alpha coefficient; (2) confirmatory factor analysis (CFA) with the survey items; (3) analysis of convergent and discriminant validity.

First, the Cronbach's alpha coefficients were $>0.86$, which explained that the internal consistency of all constructs was generally ensured (see Table 2).

CFA was performed to verify the fit of the measurement model. The results indicated that the measurement model had an acceptable model $(\chi 2(41)=171.74 ; p<0.05 ; \mathrm{GFI}=0.91$; $\mathrm{CFI}=0.95 ; \mathrm{NFI}=0.94 ; \mathrm{TLI}=0.94 ; \mathrm{IFI}=0.95 ; \mathrm{RMR}=0.04)$. As shown in Table 1 , each item loaded on its respective concept and all loading values were $>0.68$, and significant. Also, we followed Bagozzi and Yi's [56], and Fornell and Larcker's [57], frameworks, and each construct had an average variance extracted (AVE) $>0.60$ and composite reliability $(\mathrm{CR})>0.88$, which provided evidence of convergent validity between the measured variables.

Table 2. Results of the confirmatory factor analysis (CFA).

\begin{tabular}{cccccc}
\hline Construct & Items & $\lambda$ & $\alpha$ & CR & AVE \\
\hline \multirow{3}{*}{ Retailer's CSR } & R_CSR_01 & $0.68^{*}$ & & & \\
& R_CSR_02 & $0.78^{*}$ & \multirow{2}{*}{0.89} & 0.86 & 0.61 \\
& R_CSR_03 & $0.86^{*}$ & & & \\
& R_CSR_04 & $0.81^{*}$ & & & \\
Retailer Equity & RE_01 & $0.81^{*}$ & & 0.65 \\
& RE_02 & $0.81^{*}$ & \multirow{2}{*}{0.92} & & \\
& RE_03 & $0.78^{*}$ & & & \\
& RE_43 & $0.83^{*}$ & & & \\
Usage Intention & UI_1 & $0.75^{*}$ & & & \\
& UI_2 & $0.77^{*}$ & 0.86 & & \\
& UI_3 & $0.81^{*}$ & & &
\end{tabular}

Note: $\lambda=$ factor loading $\left({ }^{*} p<0.01\right) ; \alpha=$ Cronbach's alpha coefficient; $\mathrm{CR}=$ composite reliability; AVE = average variance extracted.

In addition, as shown in Table 3, the discriminant validity of the measurement was confirmed according to Fornell and Larcker [57]: The values (0.77-0.80) of the square root of the AVE for each construct exceeded the correlation coefficients $(0.63-0.69)$ between all constructs. 
Table 3. Correlation and square root of the AVE.

\begin{tabular}{cccc}
\hline & $\mathbf{1}$ & $\mathbf{2}$ & $\mathbf{3}$ \\
\hline 1. Retailer's CSR & $0.78^{+}$ & & \\
2. Retailer Equity & $0.63^{* *}$ & $0.80^{\dagger}$ & $0.77^{* *}$ \\
3. Usage Intention & $0.63^{* *}$ & $0.69^{* *}$ &
\end{tabular}

Note: ${ }^{+}=$Root of average variance extracted; ${ }^{* *}=$ correlation coefficient.

\subsection{Hypothesis Testing}

This study used structural equation modeling (SEM) to test the hypotheses. As a result, we confirmed that the fit of the research model was acceptable $(\chi 2(42)=207.94$; $p<0.05 ; \mathrm{GFI}=0.90 ; \mathrm{CFI}=0.94 ; \mathrm{NFI}=0.93 ; \mathrm{TLI}=0.93 ; \mathrm{IFI}=0.94 ; \mathrm{RMR}=0.08$ ).

H1 was to verify the effects of CSR activities on retailer equity. In Table 4, the result of this hypothesis showed that the retailer's CSR activities had a positive effect on retailer equity $(\beta=0.70 ; t=12.64 ; p<0.01)$. Hence, $\mathrm{H} 1$ is supported.

Table 4. Results of hypotheses testing.

\begin{tabular}{cccc}
\hline Hypothesis & Path & Standard $\boldsymbol{\beta}$ & $\boldsymbol{t}$-Value \\
\hline $\mathrm{H} 1$ & Retailer's CSR $\rightarrow$ Retailer Equity & $0.70^{* *}$ & 12.64 \\
$\mathrm{H} 2$ & Retailer Equity $\rightarrow$ Usage Intention & $0.77^{* *}$ & 15.82 \\
\hline Note: $^{*} p<0.05,{ }^{* *} p<0.01$. & &
\end{tabular}

As $\mathrm{H} 2$ was related to the effect of retailer equity on usage intention, the hypothesis testing showed that retailer equity had a significant positive effect on the customers' usage intention $(\beta=0.77 ; t=15.82 ; p<0.01)$. Therefore, $\mathrm{H} 2$ is also supported.

These results show that consumers estimate retailer equity to be higher from the retailer's CSR activities, which increases their intention to use the retailer.

\section{Discussion and Conclusions}

This study focused on retailers' CSR activities to solve the question of how retailers make themselves stand out and attain sustainability. Specifically, we attempted to investigate the relationships between the CSR, retailer equity, and usage intention to explain the role of CSR activities.

First, the study results showed that retailers' CSR activities had a positive effect on their equity. The results show that management and investment to improve the CSR activities of retailers increase the retailer equity. These findings have important theoretical implications in that retailer equity is a brand-new outcome variable. At the same time, we know that CSR is an important antecedent variable for the development of retailer equity. We can also suggest a practical implication from this result that retailers need to manage and develop CSR activities actively as an important marketing strategy. The development of this retailer equity is more important for retailers in a severely competitive environment because it brings various benefits as essential differentiators for competitive advantage. In particular, it will be important to discover and use various CSR activities such as environmentally friendly policies, caring about the local community, trade of local products, and fair treatment of employees.

Second, we confirmed that retailer equity has a significant positive effect on customers' usage intention. As the finding of Arnett et al. [25], and Lee and Lee [27], this study also has a theoretical implication in confirming that an important antecedent variable of usage intention is retailer equity. We also propose a managerial implication that retailer managers need to manage their retail stores as brands to maintain customers. Although the price and quality of products handled by retailers are important, efforts are needed to promote their brand concept and brand image, and to enhance the perceived quality and loyalty from customers simultaneously. In other words, retailers should always manage and measure retailer equity to increase their customer's willingness to use them and continue their relationship with customers for a long time. 
In summary, customers estimate the retailer equity as higher and better through retailers' CSR activities, which increases their intention to use the retailer. These findings provide important theoretical and practical implications. As previously described in the Introduction, scholars have suggested that we should identify the arguable causal relationship, such as whether there is a positive relationship between CSR and performance or not, and to adopt various conditional variables between them (e.g., [11,22-24]). Therefore, this study provides a theoretical implication, demonstrating the relationship indicating that retailer equity is an important mediator variable. From a retailer's management perspective, retailers should use various CSR activities strategically to improve retailer equity valued by customers and provide detailed information about the results of CSR activities to customers, which improves retailer equity in the future.

\section{Limitations and Future Research}

Despite its implications, this study has the following limitations, which could also be used as suggestions for further research.

First, this study dealt with CSR and retailer equity as a single dimension. However, several studies suggested that CSR and retailer equity could be multi-dimensional constructs (e.g., $[25,27,58])$. Therefore, future research must consider and better estimate each dimension's impacts on customer's attitudes and behaviors for identifying various impacts.

Second, we chose retailer equity as an important outcome variable for CSR. However, the distribution channel consists of various members such as wholesalers, retailers, and logistics companies in the distribution environment. Therefore, future research has to expand the scope and deal with channel equity as the benefit or leverage effect generated through a distribution channel [55]. If future research does use channel equity, it is expected that the utilization of CSR from a business-to-business (B2B) perspective will be confirmed.

Third, future research will require a wider variety of conditional variables. This study has shown that it is not an integrated approach to deal with related conditional variables because we only deal with CSR activities. Therefore, we recommend that future research continues examining CSR, considering various related variables such as CSR authenticity and CSR consistency.

Funding: This research was supported by the research fund of Hanbat National University in 2018. Institutional Review Board Statement: Not applicable.

Informed Consent Statement: Informed consent was obtained from all subjects involved in the study.

Data Availability Statement: The data presented in this study are available on request from the corresponding author. The data are not publicly available due to privacy.

Conflicts of Interest: The authors declare no conflict of interest.

\section{References}

1. Lombart, C.; Louis, D. A study of the impact of Corporate Social Responsibility and price image on retailer personality and consumers' reactions (satisfaction, trust and loyalty to the retailer). J. Retail. Consum. Serv. 2014, 21, 630-642. [CrossRef]

2. Gupta, S.; Pirsch, J. The company-cause-customer fit decision in cause-related marketing. J. Consum. Mark. 2006, $23,314-326$. [CrossRef]

3. Sen, S.; Bhattacharya, C.B. Does doing good always lead to doing better? Consumer reactions to corporate social responsibility. J. Mark. Res. 2001, 38, 225-243. [CrossRef]

4. Ramasamy, B.; Yeung, M. Chinese consumers' perception of corporate social responsibility (CSR). J. Bus. Ethics 2009, 88, 119-132. [CrossRef]

5. Gupta, S.; Pirsch, J. The influence of a retailer's corporate social responsibility program on re-conceptualizing store image. J. Retail. Consum. Serv. 2008, 15, 516-526. [CrossRef]

6. Swaen, V.; Chumpitaz, R.C. Impact of corporate social responsibility on consumer trust. Rech. Appl. Mark. 2008, 23, 7-34. [CrossRef]

7. Du, S.; Bhattacharya, C.B.; Sen, S. Reaping relational rewards from corporate social responsibility: The role of competitive positioning. Int. J. Res. Mark. 2007, 24, 224-241. [CrossRef] 
8. Hartman, K.B.; Spiro, R.L. Recapturing store image in customer-based store equity: A construct conceptualization. J. Bus. Res. 2005, 58, 1112-1120. [CrossRef]

9. Abu Bakar, A.S.; Ameer, R. Readability of corporate social responsibility communication in Malaysia. Corp. Soc. Responsib. Environ. Manag. 2011, 18, 50-60. [CrossRef]

10. Margolis, J.D.; Walsh, J.P. Misery loves companies: Rethinking social initiatives by business. Adm. Sci. Q. 2003, 48, 268-305. [CrossRef]

11. Saeidi, S.P.; Sofian, S.; Saeidi, P.; Saeidi, S.P.; Saaeidi, S.A. How does corporate social responsibility contribute to firm financial performance? The mediating role of competitive advantage, reputation, and customer satisfaction. J. Bus. Res. 2015, 68, 341-350. [CrossRef]

12. Surroca, J.; Tribó, J.A.; Waddock, S. Corporate responsibility and financial performance: The role of intangible resources. Strateg. Manag. J. 2010, 31, 463-490. [CrossRef]

13. Robinson, S.R.; Irmak, C.; Jayachandran, S. Choice of cause in cause-related marketing. J. Mark. 2012, 76, 126-139. [CrossRef]

14. Green, T.; Peloza, J. How do consumers infer corporate social responsibility? The role of organization size. J. Consum. Behav. 2014, 13, 282-293.

15. Kull, A.J.; Heath, T.B. You decide, we donate: Strengthening consumer-brand relationships through digitally co-created social responsibility. Int. J. Res. Mark. 2016, 33, 78-92. [CrossRef]

16. Ferriera, A.I.; Ribeiro, I. Are you willing to pay the price? The impact of corporate social (ir)responsibility on consumer behaviour toward national and foreign brands. J. Consum. Behav. 2017, 16, 63-71. [CrossRef]

17. Brønn, P.S.; Vrioni, A.B. Corporate social responsibility and cause-related marketing: An overview. Int. J. Advert. 2001, 20, 207-222. [CrossRef]

18. Lima Crisóstomo, V.; de Souza Freire, F.; Cortes de Vasconcellos, F. Corporate social responsibility, firm value and financial performance in Brazil. Soc. Responsib. J. 2011, 7, 295-309. [CrossRef]

19. Gössling, T. Corporate Social Responsibility and Business Performance. Theories and Evidence about Organizational Responsibility; Edward Elgar: London, UK, 2011.

20. Orlitzky, M.; Siegel, D.S.; Waldman, D.A. Strategic corporate social responsibility and environmental sustainability. Bus. Soc. 2011, 50, 6-27. [CrossRef]

21. Loussaïef, L.; Cacho-Elizondo, S.; Pettersen, I.B.; Tobiassen, A.E. Do CSR actions in retailing really matter for young consumers? A study in France and Norway. J. Retail. Consum. Serv. 2014, 21, 9-17. [CrossRef]

22. Anser, M.K.; Zhang, Z.; Kanwal, L. Moderating effect of innovation on corporate social responsibility and firm performance in realm of sustainable development. Corp. Soc. Responsib. Environ. Manag. 2018, 25, 799-806. [CrossRef]

23. Miller, S.R.; Eden, L.; Li, D. CSR reputation and firm performance: A dynamic approach. J. Bus. Ethics 2020, 163, 619-636. [CrossRef]

24. Walker, K.; Zhang, Z.; Ni, N. The mirror effect: Corporate social responsibility, corporate social irresponsibility and firm performance in coordinated market economies and liberal market economies. Br. J. Manag. 2019, 30, 151-168. [CrossRef]

25. Arnett, D.B.; Laverie, D.A.; Meiers, A. Developing parsimonious retailer equity indexes using partial least squares analysis: A method and applications. J. Retail. 2003, 79, 161-170. [CrossRef]

26. Pappu, R.; Quester, P. A consumer-based method for retailer equity measurement: Results of an empirical study. J. Retail. Consum. Serv. 2006, 13, 317-329. [CrossRef]

27. Lee, S.H.; Lee, S.H. A Scale Development of Retailer Equity. Sustainability 2018, 10, 3924. [CrossRef]

28. Sheehy, B. Defining CSR: Problems and solutions. J. Bus. Ethics 2015, 131, 625-648. [CrossRef]

29. McWilliams, A.; Siegel, D.S.; Wright, P.M. Corporate social responsibility: International perspectives. J. Bus. 2006, 23, 1. [CrossRef]

30. Mattera, M.; Baena, V.; Cerviño, J. Analyzing social responsibility as a driver of firm's brand awareness. Procedia Soc. Behav. Sci. 2012, 58, 1121-1130. [CrossRef]

31. Rahdari, A.; Sheehy, B.; Khan, H.Z.; Braendle, U.; Rexhepi, G.; Sepasi, S. Exploring global retailers' corporate social responsibility performance. Heliyon 2020, 6, e04644. [CrossRef]

32. Luo, X.; Bhattacharya, C.B. Corporate social responsibility, customer satisfaction, and market value. J. Mark. 2006, 70, 1-18. [CrossRef]

33. Oppewal, H.; Alexander, A.; Sullivan, P. Consumer perceptions of corporate social responsibility in town shopping centres and their influence on shopping evaluations. J. Retail. Consum. Serv. 2006, 13, 261-274. [CrossRef]

34. Ameer, R.; Othman, R. Sustainability practices and corporate financial performance: A study based on the top global corporations. J. Bus. Ethics 2012, 108, 61-79. [CrossRef]

35. Von Arx, U.; Ziegler, A. The effect of corporate social responsibility on stock performance: New evidence for the USA and Europe. Quant. Financ. 2014, 14, 977-991. [CrossRef]

36. Schramm-Klein, H.; Morschett, D.; Swoboda, B. Retailer corporate social responsibility: Shedding light on CSR's impact on profit of intermediaries in marketing channels. Int. J. Retail Distrib. Manag. 2015, 43, 403-431. [CrossRef]

37. Anastasiadou, E.; Lindh, C.; Vasse, T. Are consumers international? A study of CSR, cross-border shopping, commitment and purchase intent among online consumers. J. Glob. Mark. 2019, 32, 239-254. [CrossRef]

38. Diallo, M.F.; Lambey-Checchin, C. Consumers' perceptions of retail business ethics and loyalty to the retailer: The moderating role of social discount practices. J. Bus. Ethics 2017, 141, 435-449. [CrossRef] 
39. Valenzuela, L.M.; Mulki, J.P.; Jaramillo, J.F. Impact of customer orientation, inducements and ethics on loyalty to the firm: Customers' perspective. J. Bus. Ethics 2010, 93, 277-291. [CrossRef]

40. Andrews, M.; Luo, X.; Fang, Z.; Aspara, J. Cause marketing effectiveness and the moderating role of price discounts. J. Mark. 2014, 78, 120-142. [CrossRef]

41. Mark-Herbert, C.; Von Schantz, C. Communicating Corporate Social Responsibility-Brand Management. Electron. J. Bus. Ethics Organ. Stud. 2007, 12, 4-11.

42. Blumenthal, D.; Bergstrom, A. Brand councils that care: Towards the convergence of branding and corporate social responsibility. J. Brand Manag. 2003, 10, 327-341. [CrossRef]

43. Jinfeng, W.; Zhilong, T. The impact of selected store image dimensions on retailer equity: Evidence from 10 Chinese hypermarkets. J. Retail. Consum. Serv. 2009, 16, 486-494. [CrossRef]

44. Cuesta-Valiño, P.; Rodríguez, P.G.; Núñez-Barriopedro, E. The impact of corporate social responsibility on customer loyalty in hypermarkets: A new socially responsible strategy. Corp. Soc. Responsib. Environ. Manag. 2019, 26, 761-769. [CrossRef]

45. McWilliams, A.; Siegel, D.S.; Wright, P.M. Corporate social responsibility: Strategic implications. J. Manag. Stud. 2005, 43, 1-18. [CrossRef]

46. Schramm-Klein, H.; Zentes, J. Corporate Social Responsibility of Retail Companies: Is It Relevant for Consumers' Purchasing Behavior; Institute for Commerce \& International Marketing Saarland University: Saarbrücken, Germany, 2008; Available online: http:/ / institut-gestion.univlarochelle.fr/IMG/pdf/Corporate_Social_Responsibility_of_Retail_Companies.pdf (accessed on 15 January 2021).

47. Keller, K.L.; Lehmann, D.R. How do brands create value? Mark. Manag. 2003, 12, 26-31.

48. Ailawadi, K.L.; Keller, K.L. Understanding retail branding: Conceptual insights and research priorities. J. Retail. 2004, 80, 331-342. [CrossRef]

49. Putra, A.P.; Armanu, A.; Sudjatno, S. The influence of corporate social responsibility, brand personality and corporate reputation on brand loyalty of modern retailers. J. Apl. Manaj. 2019, 17, 66-75. [CrossRef]

50. Ailawadi, K.L.; Neslin, S.A.; Luan, Y.J.; Taylor, G.A. Does retailer CSR enhance behavioral loyalty? A case for benefit segmentation. Int. J. Res. Mark. 2014, 31, 156-167. [CrossRef]

51. Dang, V.T.; Nguyen, N.; Pervan, S. Retailer corporate social responsibility and consumer citizenship behavior: The mediating roles of perceived consumer effectiveness and consumer trust. J. Retail. Consum. Serv. 2020, 55, 102082. [CrossRef]

52. Verhoef, P.C.; Langerak, F.; Donkers, B. Understanding brand and dealer retention in the new car market: The moderating role of brand tier. J. Retail. 2007, 83, 97-113. [CrossRef]

53. Swoboda, B.; Berg, B.; Schramm-Klein, H.; Foscht, T. The importance of retail brand equity and store accessibility for store loyalty in local competition. J. Retail. Consum. Serv. 2013, 20, 251-262. [CrossRef]

54. Grace, D.; O'Cass, A. An examination of the antecedents of repatronage intentions across different retail store formats. J. Retail. Consum. Serv. 2005, 12, 227-243. [CrossRef]

55. Londoño, J.C.; Elms, J.; Davies, K. Conceptualising and measuring consumer-based brand-retailer-channel equity. J. Retail. Consum. Serv. 2016, 29, 70-81. [CrossRef]

56. Bagozzi, R.P.; Yi, Y. On the evaluation of structural equation models. J. Acad. Mark. Sci. 1988, 16, 74-94. [CrossRef]

57. Fornell, C.; Larcker, D.F. Evaluating structural equation models with unobservable variables and measurement error. J. Mark. Res. 1981, 18, 39-50. [CrossRef]

58. Servera-Francés, D.; Fuentes-Blasco, M. The Relationship of Corporate Social Responsibility, Consumer Value, Satisfaction and Loyalty: An Empirical Study. Ramon Llull J. Appl. Ethics 2016, 7, 167-190. 